\title{
COMPARISON OF FINANCIAL PERFORMANCE OF GOVERNMENT BANKS AND NATIONAL PRIVATE BANKS IN BOOK CATEGORY 4
}

\author{
Thea Agatha Kurniawan \\ Bambang Mulyana \\ Asep Risman
}

Mercu Buana University, Jakarta, Indonesia

The purpose of this research is to compare empirically the performance of government banks and national private banks in the period of 2014-2019. The population in this study includes government-owned banks (BUMN) and national private banks (BUSN) registered in BUKU 4. The statistical method used has been t-test for different variants (unequal variance) with the separated variance formula. Data processing to compare the financial performance of government banks and national private has been based on the independent sample t-tests. The results show that there are differences when using several measuring instruments.

Keywords: financial performance; government banks; private banks; Indonesia; t-test.

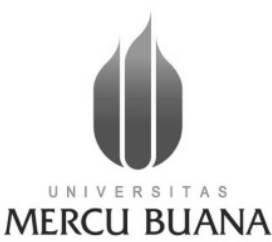

MERCU BUANA

\section{Thea Agatha Kurniawan}

Researcher, Faculty of Economy and Business, University "Universitas Mercu Buna", Jakarta Indonesia

Research interests: financial stability, corporative finance, international and national business development

Email: theaagatha55@gmail.com

\section{Bambang Mulyana}

Researcher, Faculty of Economy and Business, University "Universitas Mercu Buna”, Jakarta Indonesia

Research interests: banking and financing, international financial markerts

Email: theaagatha55@gmail.com

\section{Asep Risman}

Lecturer of University “Universitas Mercu Buna”, Jakarta Indonesia.

Research interests: corporative finance, corporative management, international and national business development

E-mail: asep.risman@mercubuana.ac.id 


\section{Introduction}

Banking is an economic sector that produces financial services and also a sector that is very influential for economic growth in many countries, including Indonesia. Any bank aims to raise funds from the community in the form of deposits and channel those funds back to the community in the form of loans and the like. Therefore, banks have the mediating role as they are facilitating exchange, assisting the formation of capital, and contributing to economic and social justice through more equitable income and general welfare.

In practice, since October 1988 state-owned banks and national private banks in Indonesia compete openly. Therefore, they are encouraged to maintain their financial performance. Facing intense competition between banks, the financial condition of banks is one of the factors that must be maintained in order to survive. Financial performance is part of a bank's overall performance.

Sound financial performance demonstrates the bank's ability to manage its finances well and its capability to use all its assets to generate optimal returns. Some research on the comparison of bank performance based on the ratios of financial statements has been done before, namely, by means of using Return on Asset (ROA), Return on Equity (ROE) and Loan to Deposit Ratio (LDR) indicators (Febryani \& Zulfadin, 2003: 4).

Research on banking performance in Indonesia has been done quite a lot with different emphases put on segmentation or group. For example, Mulyana (2018) conducted a research on the performance of banks and found there was no significant difference in financial performance between the two groups of banks. This research has been conducted at the BUKU 4 (BOOK 4) level, with consideration that these banks are the locomotive of banking in Indonesia and become the choice for the majority of population. Before we look at the assets data of each bank, we must first look at the economic growth data according to BPS (the Central Statistics Agency), see Tab. 1 below.

Table 1 - Economic Growth of Indonesia

(Source: Central Statistics Agency)

\begin{tabular}{|c|c|}
\hline Year & Economic growth rate, $\%$ \\
\hline 2015 & 4,79 \\
\hline 2016 & 5,02 \\
\hline 2017 & 5,07 \\
\hline 2018 & 5,17 \\
\hline 2019 & 5,02 \\
\hline
\end{tabular}

From the BPS data, it is necessary to know whether state-owned banks and national private banks are equally performing. We can obviously see that financial assets of state banks were increasing while in private banks there was a decline although economic growth data has been demonstrating a rising trend.

Based on such a background, it is necessary to conduct research that would raise the topic of comparing financial performance of government banks with that of national private banks under the book category 4. 


\section{COMPARISON OF FINANCIAL PERFORMANCE OF}

\section{Study Theory}

\section{Definition of a Bank}

According to Statements of Accounting Standards (PSAK) No. 31 bank is "an institution that serves as a financial intermediary between parties who have excess funds (surplus units) with parties who need funds (unit deficit) and as an institution that serves to facilitate payment traffic". Garrison (2000) defined banks as financial institutions the main activities of which are to raise funds from the community and re-channel these funds back to the community in the course of providing bank services. While the understanding of financial institutions overall is somewhat different: this is any company engaged in financial activities, be it raising funds, or only channeling funds, or both collecting and channeling.

\section{Financial Statements}

Financial management is inseparable from financial statements. Financial statements are prepared with the aim of providing financial information on a company to all interested parties as part of their decision-making process. According to Sundjaja \& Barlian (2003), financial statements are part of the financial reporting process consisting of loss statements, balance sheets, retained earnings reports and cash flow statements. Meanwhile, according to Kasmir (2003), Risman et al. (2020) financial statements are historical documents, as they tell us what has happened during a certain year or a certain series of years. Finally according to Harahap (2002), financial statements are reports that describe the financial condition and the results of a company at a certain time or over a certain period of time.

\section{Financial Performance}

Company's performance is often measured through quantification and effectiveness in business operations during a certain period (Anggraini et al., 2015). Financial performance is expected to assess the financial condition and the performance of a company, and this sort of an analysis requires several benchmarks to be used as ratios and indices connecting various financial data into one scope (Sawir, 2005, Risman et al., 2021a). Financial performance is the result of individual decisions made continuously by management. Thus, performance results from good or poor decisions taken by management. Financial performance can be measured through evaluation of financial statements. Information generated by financial positioning and past financial performance is sometimes used as the basis for predicting future financial position and performance.

\section{Hypotheses}

Based on the literature study and the research framework of our own, several research hypotheses are proposed as follows:

- There is no difference in NPL between a government bank and a national private bank.

- There are differences in LDR between government banks and national private banks.

- There is a difference in the composite value of good corporate governance between government banks and national private banks.

- There is no significant difference in ROA between government banks and private banks. 
- There is no difference in ROE between government banks and private banks.

- There is a difference in NIM between government and private banks.

- There is a difference in LOI between government banks and private banks.

- There is a significant difference in the CAR ratio between government banks and private banks.

\section{Research Methods}

\section{Population and Sample}

Population is a generalization area consisting of objects or subjects that have certain qualities and characteristics that can be determined by researchers and then studied with the aim to draw some conclusions (Sugiyono, 2016: 80). The population in this study is government banks and national private banks of Indonesia listed in BUKU 4.

In this study we have used the saturated sample method. This is a technique applied for determining the sample when all the members of the population are used as a sample. Thus, our research was conducted on all government and national private banks listed in BUKU 4 .

\section{Research Measuring Instruments}

Components of financial performance factors used in this research are Risk Profile, Good Corporate Governance, Earning and Capital. As stipulated in Bank Indonesia Circular Letter No. 31/1/PBI/2011, financial performance factors are represented here by the following variables:

\section{Risk Profile}

Risk profile is measured using credit risk and liquidity risk, following the formula 1,2 consequently:

$$
\begin{aligned}
& N P L=\frac{\text { Total Non-Performing Loans }}{\text { Total Credit }} \times 100 \% \\
& L D R=\frac{\text { Total Credit Volume }}{\text { Total Fund Receipts }} \times 100 \%
\end{aligned}
$$

\section{Good Corporate Governance}

Assessing following the data and methodology in Tab. 2

\section{Earnings}

Return on Assets (3), Return on Equity (4), Net Interest Margin (5), Operations load on operational income (6)

$$
R O A=\frac{\text { Profit Before Tax }}{\text { Total Assets }} X 100 \%
$$




\section{COMPARISON OF FINANCIAL PERFORMANCE OF}

$$
\begin{aligned}
& R O E=\frac{\text { Net Profit }}{\text { Total Assets }} \times 100 \% \\
& N I M=\frac{\text { Interest Income-Interest Expense }}{\text { Productive Assets }} \times 100 \% \\
& L O I=\frac{\text { Operational load }}{\text { Total operational income }} \times 100 \%
\end{aligned}
$$

Table 2 - Methodology of corporate governance assessment in banks (Source: Central Bank of Indonesia)

The Weight Of The GCG Implementation Assessment

\begin{tabular}{|c|l|c|}
\hline NO & \multicolumn{1}{|c|}{ FACTOR } & WEIGHT (\%) \\
\hline 1 & Executing the duties and responsibilities of the board of commissioners & $12.5 \%$ \\
\hline 2 & Executing the duties and responsibilities of the board of directors & $17.5 \%$ \\
\hline 3 & Completeness and implementation of committee duties & $10 \%$ \\
\hline 4 & Implementation of DPS duties and responsibilities & $5 \%$ \\
\hline 5 & Implementation of sharia principles in raising funds and channeling funds & $10 \%$ \\
\hline 6 & Handling conflicts of interest & $5 \%$ \\
\hline 7 & Implementing the compliance function & $5 \%$ \\
\hline 8 & Implementing the internal audit function & $5 \%$ \\
\hline 9 & Implementation of the external audit function & $5 \%$ \\
\hline 10 & Maximum limit of fund distribution & $15 \%$ \\
\hline 11 & Transparent financial and non-financial conditions, GCG implementation & $100 \%$ \\
\hline & reports and internal reporting & \\
\hline
\end{tabular}

\section{Capital}

Capital Adequacy Ratio (7)

$$
C A R=\frac{\text { Capital }}{A T M R} X 100 \%
$$

\section{Research Design}

This research is a comparative one since it compares the selected parameters of the equivalent objects. Testing comparative hypotheses means testing population parameters in the form of differences (Sugiyono, 2009:115).

In this study, for the purposes of our comparative analysis, we have utilized quantitative data and applied difference analysis to it in the form of ratio figures obtained and described in accordance with the central problem to be examined (Risman, 2021b). This research will analyze the financial performance of the two groups of banks using historical data derived from the financial statements of these banks. 


\section{Data Analysis Method}

\section{Descriptive Statistics}

Descriptive statistics is used here to analyze data by describing it without the intention to make conclusions or generalizations. Descriptive statistics can be used if the researcher only wants to describe sample data, and does not want to make conclusions that apply to the population where the sample was taken. In this study, descriptive statistics are needed for a fuller picture.

\section{Test Normality}

Normality tests are usually used to determine whether data population is distributing normally or not. For this, we have used the SPSS program for the data with the significance level of 0.05 . If the value is above 0.05 , then the data distribution is declared to meet the assumption of normality, and if the value is below 0.05 - then it is interpreted as being abnormal.

\section{Homogeneity Test}

Homogeneity tests are used to check whether the variance of each group is the same. The normality test in this study is the Bartlett test performed in SPSS, determining the significance level $(\alpha)$ of 0.05 .

\section{ANOVA Test}

Variance analysis is a statistical procedure applied to determine whether the mean of three or more populations is equal or different. In the ANOVA test, sample evidence is taken from each population under consideration. The data obtained from the sample is used to calculate sample statistics. Sampling distribution is then used to reject or accept the zero hypothesis ( $\mathrm{H} 0)$ : if the calculated $\mathrm{F}>\mathrm{F}$ table value, then reject $\mathrm{H} 0$; if calculated $\mathrm{F}<\mathrm{F}$ table value, then accept $\mathrm{H} 0$.

\section{Kruskal Wallis Test}

The Kruskal Wallis test is one of the nonparametric tests applied to relation to independent samples. This method of testing is used when the assumption under ANOVA test is not met, i.e., each sample group is distributed normally.

The final result of Kruskal Wallis test is p-value. If this value is $<$ critical limit $(\alpha)$, then we conclude that there is a difference in the sample group, whereas if the value $p$ value $>$ critical limit $(\alpha)$, then we conclude that there is no difference in the sample.

\section{Data Analysis}

Data analysis is always performed in several steps. For the purposes of this research we have taken the following steps:

1. Collect data in the form of bank financial statements by means of downloading these publicly available financial statements from the banks' official websites.

2. Group data accordingly on the variables we plan to operate.

3. Pair the sample T-test if under the normal distribution test the data used is normally distributed. 


\section{COMPARISON OF FINANCIAL PERFORMANCE OF}

\section{Statistical testing}

This test was conducted by means of testing the financial ratios of government banks and private national banks. The results of this test are expected to determine if there are any noticeable differences in financial performance between the two groups of banks.

\section{Results and Discussions}

\section{Data Analysis}

To analyze the financial performance of national private banks we have used financial ratios contained in their 2015-2019 financial statements, and these financial ratios include the following:

$N P L$

The minimum NPL value generated within the national private banks group belonged to Bank BCA, and it was $0.75 \%$ (back in 2015). Meanwhile, the maximum value was generated by the Bank Pemerintah group, namely Bank Mandiri, and it was 3.96\% in 2016.

\section{$L D R$}

The minimum LDR was generated by the Bank BCA and it was at $77.12 \%$ back in 2016. While the maximum value was generated by Bank PANIN - $115.26 \%$ in 2019.

\section{$R O A$}

The minimum ROA value was generated by Bank PANIN, 1.31\% back in 2015. While the maximum value was generated by Bank BRI - 4.19\% in 2015 .

\section{$R O E$}

The minimum ROE value was generated by Bank Cimb Niaga, it was $1.51 \%$ back in 2015. While the maximum value was generated by Bank BRI - 29.89\%, also in 2015.

\section{NIM}

The minimum NIM value was generated by Bank Cimb Niaga, 2.29\% in 2016. While the maximum value was generated by Bank BRI, 8.13\% back in 2015 .

\section{LOI}

The minimum LOI value was generated by Bank BCA, at $58.63 \%$ in 2017. While the maximum value was generated by Bank Cimb Niaga - 97.38\% in 2015.

$C A R$

The minimum value of CAR was demonstrated by the Bank Mandiri, at $16.24 \%$ back in 2015. Meanwhile, the maximum value was generated by Bank BCA, 23.46\% in 2019.

\section{Data Normality Testing}

This test has been carried out to determine the distribution of measuring instrument data used in this study. Information about the normality of data is used to determine the statistical tools for hypotheses testing, i.e., if the data is distributed normally, then the 
statistical tool used for further examination of the hypotheses is a different t-test. And if data is not distributed normally, then the statistical tool used for testing the hypotheses is the Mann-Whitney test.

For data normality testing, this study has used the Kolmogorov-Smirnov test with the test result criteria of asym.sig being greater than the level of research significance of $5 \%$. Then the data is declared to be normally distributed, but if asym.sig is less than $5 \%$, then it can be stated that the data is not distributed normally.

\section{Normality Test Results}

The results we've obtained show that asym.sig for government banks in part pf NPL, ROA, ROE, NIM, LOI, and CAR is greater than 0.05 , so it can be stated that data distribution at state-owned banks in part of NPL, ROA, ROE, NIM, LOI, CAR normal is 0.125 for NPL, for ROA it is 0.200 , for ROE it is 0.162 , for NIM it is 0.200 , for LOI it is 0.183 and for CAR it is 0.200 .

The asym.sig values for private banks NPL, ROA, NIM, and CAR measuring instruments are greater than 0.05 , so it can be stated that the distribution of private banks data for NPL, ROA, NIM, and CAR is normal by 0.129 for NPL, for ROA it is 0.200 , for NIM it is 0.96 , and for CAR it is 0.200 . Thus, private banks' results indicate that in testing the average difference for NPL, ROA, NIM and CAR between state-owned banks and national private banks we would need to be using different t-tests. Meanwhile, for other measuring instruments, namely, LDR, ROE, and LOI, the results show that the data was not distributed normally, we will be operating the Kruskal-Wallis test for them.

\section{Homogeneity Test}

In theory, the homogeneity test aims to test the dependent variables in order to see whether variables have the same variants in each independent variable category (Ghozali, 2011). Our calculations show that the Sig value for ROA is 0.110 , because the value of Sig. is 0.110 which is $>0.05$. This can be interpreted that the ROA data variants for state-owned banks and national private banks are homogeneous. The Sig. value for the ROE variable is 0.083 , which is obviously $>0.05$.

Therefore, ROE data variants of the state-owned banks and national private banks is also homogeneous. The Sig, value of NIM is 0.512 , again, this is $>0.05$, and homogeneous. The Sig. value for CAR is 0.269 , also $>0.05$ and homogeneous. In cases of NPL, LDR, and LOI the measuring instruments are insignificant at 0.05 , which means the zero hypothesis cannot be rejected stating the same variance, thus meaning the ANOVA assumption has been met. Homogeneously distributed data is thus observed in all cases under consideration, except NIM, with its Sig. value of 0.000 , or $\mathrm{p}<0.005$.

According to (Ghozali, 2011: 75), if there is data that is not homogeneous, as long as the group has the same sample size, then it is not fatal for ANOVA and the analysis can still be continued.

\section{ANOVA test}

The NPL calculated F-value is 0.020 , with the probability of 0.888 , which means that $\mathrm{p}>0.05$. Thus, both groups in our sample have significantly different NPL averages. While the $\mathrm{F}$ value calculated for LDR is 3,793 with the probability of 0.062 which means $\mathrm{p}>0.05$, then the two sample groups have significantly different LDR averages. Thus, the results of 


\section{COMPARISON OF FINANCIAL PERFORMANCE OF}

this test lead to accepting $\mathrm{H} 0$ and rejecting $\mathrm{H} 1$ since there are insignificant differences in the risk profile indicators of state-owned banks and private banks.

Table 3 - Results of ANOVA test

(calculated by co-authors)

\begin{tabular}{|c|c|c|c|c|c|c|}
\hline & \multicolumn{6}{|c|}{ Hasil Uji ANOVA } \\
\hline & & $\begin{array}{l}\text { Sum of } \\
\text { Squares }\end{array}$ & $\mathrm{Df}$ & $\begin{array}{l}\text { Mean } \\
\text { Square }\end{array}$ & $\mathrm{F}$ & Sig. \\
\hline $\mathrm{N}$ & Between Groups & 0,013 & 1 & 0,013 & 0,020 & 0,888 \\
\hline $\mathrm{P}$ & Within Groups & 18,332 & 28 & 0,655 & & \\
\hline $\mathrm{L}$ & Total & 18,346 & 29 & & & \\
\hline $\mathrm{L}$ & Between Groups & 200,157 & 1 & 200,157 & 3,793 & 0,062 \\
\hline D & Within Groups & 1477,621 & 28 & 52,772 & & \\
\hline $\mathrm{R}$ & Total & 1677,778 & 29 & & & \\
\hline $\mathrm{R}$ & Between Groups & 1,733 & 1 & 1,733 & 2,858 & 0,102 \\
\hline $\mathrm{O}$ & Within Groups & 16,977 & 28 & 0,606 & & \\
\hline A & Total & 18,710 & 29 & & & \\
\hline $\mathrm{R}$ & Between Groups & 329,677 & 1 & 329,677 & 10,569 & 0,003 \\
\hline $\mathrm{O}$ & Within Groups & 873,385 & 28 & 31,192 & & \\
\hline E & Total & 1203,062 & 29 & & & \\
\hline $\mathrm{N}$ & Between Groups & 12,753 & 1 & 12,753 & 10,838 & 0,003 \\
\hline I & Within Groups & 32,947 & 28 & 1,177 & & \\
\hline M & Total & 45,700 & 29 & & & \\
\hline B & Between Groups & 481,601 & 1 & 481,601 & 7,471 & 0,011 \\
\hline $\mathrm{O}$ & Within Groups & 1804,968 & 28 & 64,463 & & \\
\hline $\begin{array}{l}\mathrm{P} \\
\mathrm{O}\end{array}$ & Total & 2286,569 & 29 & & & \\
\hline $\mathrm{C}$ & Between Groups & 0,866 & 1 & 0,866 & 0,196 & 0,662 \\
\hline A & Within Groups & 123,892 & 28 & 4,425 & & \\
\hline $\mathrm{R}$ & Total & 124,758 & 29 & & & \\
\hline
\end{tabular}

The Tab. 3 above shows that F-value calculations, with the ROA of 28.58 and the probability of 0.102 which means $\mathrm{p}<0.05$. Then, the three sample groups have the ROA average that does not differ significantly. F-value calculated for ROE is 10,569 with the probability of 0.003 which means $\mathrm{p}>0.05$. Thus, both sample groups have significant ROE averages. Furthermore, the value of F calculated for NIM is 10.838 with the probability of 0.003 which means $\mathrm{p}>0.05$. Thus, the two sample groups have significantly different NIM averages. This leads us to rejecting $\mathrm{H} 0$ and accepting $\mathrm{H} 1$ since there are significant differences in the risk earning indicators between the state-owned banks and the private banks in Indonesia.

The value of $\mathrm{F}$ calculated for LOI is 7,471 with the probability of 0.011 which means $\mathrm{p}<0.05$ Thus, the two sample groups have LOI means that are not different. F-value calculated at CAR ratio of 0.196 with the probability of 0.662 means $p>0.05$. Thus, the sample groups in question have different CAR averages. THerefore, for LOI we accept H0 and reject $\mathrm{H} 1$, as there is no significant difference. At the same time, for CAR we reject $\mathrm{H} 0$ and accept $\mathrm{H} 1$ since there is a significant difference in the capital indicators of financial performance between state-owned banks and private banks.

\section{Kruskal-Wallis Test}

Now we know that the asymp value of Sig. NPL was 0.576 which is $>0.05$. Thus, it can be concluded that $\mathrm{HO}$ is accepted and $\mathrm{H} 1$ is rejected which means there is no noticeable (significant) difference between state-owned banks and private banks. The known value of Asymp. Sig. on the ROE measuring instrument is $0.011<0.05$. Thus, $\mathrm{H} 0$ is rejected and $\mathrm{H} 1$ is 
accepted which means there is a real difference (significant) between state-owned banks and private banks. The known value of Asymp. Sig. NIM is 0.002 which is $<0.05$. Thus, $\mathrm{H} 0$ gets rejected and $\mathrm{H} 1$ gets accepted which means there is a real (significant) difference between state-owned banks and private banks. It is known that the value of Asymp. Sig. for LOI is 0.008 which is $<0.05$. Thus, it can be concluded that $\mathrm{H} 0$ is rejected and $\mathrm{H} 1$ is accepted as there is a real (significant) difference between state-owned and private banks.

\section{Data Analysis}

For the NPL variable the Sig value. (2-tailed) is 0.910 which is $>0.05$. Thus, there is no significant difference between state-owned banks and private banks. On the LDR side, the Sig value. (2-tailed) is 0.049 which is slightly $<0.05$.

Table 4 - Results of Paired Samples test (calculated by co-authors)

\section{Hasil Uji Paired Samples Test}

\begin{tabular}{|c|c|c|c|c|c|c|c|c|c|}
\hline & & & & aired Differ & ences & & & & \\
\hline & & & & Std. Error & $\begin{array}{r}95 \% \text { Confiden } \\
\text { Diff }\end{array}$ & terval of the & & & Sig. \\
\hline & & Mean & Deviation & Mean & Lower & Upper & $\mathrm{T}$ & $\mathrm{Df}$ & (2-tailed) \\
\hline & NPL &,- 04200 & 1,41249 &, 36470 &,- 82421 &, 74021 &,- 115 & 14 &, 910 \\
\hline & LDR & $-5,16600$ & 9,25897 & 2,39066 & $-10,29345$ &,- 03855 & $-2,161$ & 14 & ,049 \\
\hline & ROA & ,48067 & 1,16078 & ,29971 &,- 16215 & 1,12348 & 1,604 & 14 & ,131 \\
\hline Pair 1 & ROE & 6,63000 & 9,49101 & 2,45057 & 1,37405 & 11,88595 & 2,705 & 14 &, 017 \\
\hline & NIM & 1,30400 & 1,79488 & ,46344 &, 31003 & 2,29797 & 2,814 & 14 &, 014 \\
\hline & BOPO & $-8,01333$ & 12,72278 & 3,28501 & $-15,05897$ &,- 96769 & $-2,439$ & 14 &, 029 \\
\hline & CAR &,- 33980 & 3,02183 &, 78023 & $-2,01323$ & 1,33363 &,- 436 & 14 & ,670 \\
\hline
\end{tabular}

Thus, there is a significant difference between government banks and private banks in this aspect. For ROA, the Sig. value (2-tailed) is 0.131 which is $>0.05$, thus, there is no significant difference between government banks and private banks. For ROE, the value of Sig. (2-tailed) is 0.017 which is $<0.05$, thus, there is a significant difference between stateowned and private banks. In case of LOI, the Sig. value (2-tailed) is 0.029 which is $<0.05$, thus, there is a significant difference between state-owned and private banks. For CAR, the Sig. value (2-tailed) is 0.670 which is $>0.05$, thus, there is no significant difference between state-owned banks and private banks.

\section{Discussion}

\section{NPL}

The highest NPL mean value was achieved by private banks at $2.5713 \%$, while government-owned banks got $2.5293 \%$. Our results also show that national private banks have higher NPL averages than those of state-owned banks. The results of this statistical 


\section{COMPARISON OF FINANCIAL PERFORMANCE OF}

testing indicate that state-owned banks have a better financial performance as measured by NPLs as compared to national private banks.

\section{LDR}

The highest mean LDR value was achieved by private banks at $94.2780 \%$, while government banks got $89.1120 \%$. The national private banks also have a higher average LDR than the average LDR of state-owned banks. The results of this statistical testing indicate that the LDR of private banks tends to be more aggressive than that of state-owned banks.

\section{GCG}

Obtained data shows that state-owned banks have a very healthy GCG average as compared to national private banks. The results of statistical testing demonstrate that stateowned banks have better corporate governance as measured by GCG as compared to national private banks.

\section{ROA}

The highest ROA mean value was achieved by the group of state-owned banks at $3.080 \%$, while the national private banks groups got only $2.6000 \%$.

The data also shows that state-owned banks have a higher average ROA than that of national private banks. The results of our statistical testing demonstrate that state-owned banks have financial performance measured by a much better ROA as compared to national private banks.

\section{ROE}

The highest ROE mean value was achieved by the state-owned banks group at $18.0920 \%$, while the same indicator for national private banks was $11.2620 \%$.

State-owned banks have a higher ROE average as compared to national private banks. The results of our statistical testing indicate that state-owned banks have a better financial performance when measured by ROE and compared with national private banks.

\section{NIM}

The highest NIM mean value was also achieved by the state-owned banks group at $6.3747 \%$, while the national private banks got only $5.0707 \%$.

Our results show that state-owned banks have a higher average NIM as compared to national private banks. The results of the statistical testing demonstrate that state-owned banks have a better financial performance as measured by NI as compared to the group of national private banks.

\section{LOI}

The highest LOI mean value was achieved by the national private banks group at $79.9493 \%$, while the same indicator for the group of state-owned banks was $70.9360 \%$.

Our data and calculations on it show that private banks have a higher LOI average than that of state-owned banks. These results of the statistical testing indicate that state-owned banks have better financial performance as measured by LOI than the national private banks. 


\section{CAR}

The highest CAR mean value was achieved by the group of national private banks and it was $20.9080 \%$, while the group of state-owned banks got $20.5682 \%$.

Our results show that national private banks have a higher average CAR as compared to state banks. The results of the statistical testing prove that national private banks have a better financial performance as measured by CAR as compared to state-owned banks in Indonesia.

\section{Conclusions}

From the analysis and the discussion above, we conclude as follows:

- For the NPL measuring instrument, it is proven that there is no significant difference between state-owned and national private banks.

- For the LDR measuring instrument, we have observed a significant difference between state-owned and national private banks.

- GCG of government banks proved to be better as compared to national private banks.

In part of ROA measuring instrument, there is no significant difference between stateowned and national private banks.

Concerning ROE, there are significant differences between state-owned banks and national private banks.

In part of NIM measuring instrument, we have found that there are significant differences between state-owned and national private banks.

In part of LOI, there are significant differences between state-owned banks and national private banks.

In terms of CAR, there is no significant difference between state-owned and national private banks.

In general, financial performance of state-owned banks is better than that of national private banks. After testing the descriptive statistics we have concluded that the average CAR of a national private bank is greater than that of a state-owned bank. Therefore, in terms of capital ownership, national private banks are doing better than the state-owned banks.

The mean ROA value of state-owned banks is greater than that of national private banks, which means that the ratio of net income to assets of state-owned banks is better than that of commercial banks. The mean ROE value in the group of state-owned banks is greater than that of national private banks, which means that the ratio of net income to equity of state-owned banks is better than that of national private banks.

The mean LOI value of national banks is greater than that of state-owned banks. In other words, the efficiency performance of the banks owned and managed by the state is better than that of private banks. The mean LDR value of national private banks is greater than that of state-owned banks. Or in other words, liquidity of private banks is better than that of state-owned banks.

The NPL mean value of state-owned banks is greater than that of national private banks. The mean NIM value of state-owned banks is greater than that of private banks, so the net interest income from the state-owned bank assets is better than that of assets of the national private banks. 


\section{COMPARISON OF FINANCIAL PERFORMANCE OF}

Finally, the mean GCG value of state-owned banks is better than that of national private banks. This can be interpreted as follows: corporate governance within state-owned banks is generally better than that in national private banks in Indonesia.

\section{References:}

Anggraini, M., Moch Dzulkirom, A.R., \& Saifi, M. (2015). Analysis of The Financial Performance of Conventional Banks and Islamic Banks. Jurnal Administrasi Bisnis, 27(1).

Arbi, S. (2003). Get To Know Banks and Non-Bank Financial Institutions, Jakarta: Djambatan.

Febryanti, A., \& Rahadian, Z. (2003). Analysis of The Performance of Foreign Exchange Banks and Non-Foreign Exchange Banks in Indonesia. Journal of Economic and Financial Studies, 7(4).

Garrison, R. H. (2000). Management Accounting. Yogyakarta: AK Group.

Ghozali, I. (2011). Multivariate Analysis with the SPSS Program. Semarang: Badan Penerbit Universitas Dipenogoro.

Harahap, S. S. (2002). Critical Analysis of Financial Reports. Jakarta: PT.Raja Grafindo Persada.

Kasmir (2003). Banking Management. Jakarta: PT. Raja Grafindo Persada.

Mulyana, B. (2018). Financial Performance of Foreign Exchange Bank and Non Foreign Exchange Bank in Indonesia 2012-2016 Periods. Scholar Journal of Economics, Business and Management, 5(6), 444-453.

Risman, A., Parwoto \& Sulaeman, A. (2020). The Mediating Role of Firm's Performance on The Relationship between Free Cash Flow and Capital Structure, Psychology and Education Journal, 58 (1), 1209-1216.

Risman, A., Mulyana, B., Silvatika, B., \& Sulaeman, A. (2021). The Effect of Digital Finance on Financial Stability. Management Science Letters, 11(7), 1979-1984.

Risman, A., Subhani, M., \& Ushakov, D. (2021). Nexus between Financial Fundamentals and Automotive (Car) Industry. ARDL approach. E3S Web of Conferences, 244.

Sawir, A. (2005). Financial Performance Analysis and Corporate Financial Planning. Jakarta: PT Gramedia Pustaka.

Sugiyono (2016). Quantitative, Qualitative and R\&D Research Methods. Bandung: PT Alfabet.

Sundjaya, Ridwan S., \& Inge Barlian (2003). Financial Management. Jakarta: Literata Lintas Media.

Paper submitted

Paper accepted for publishing

Paper published online
02 March 2021

16 April 2021

31 May 2021 